\title{
Audit on compliance of ventilator associated pneumonia care bundle in Intensive Care units in National Hospital Sri Lanka
}

\author{
Ruvini Jayanimali Kosgollawatta Walimanna Gamage ${ }^{1^{*}}$ \\ Specialty Registrar in Anaesthesia and Critical Care, North Wick Park Hospital, United Kingdom.
}

\begin{abstract}
Introduction: Nosocomial infections are a major health concern worldwide, ventilatorassociated pneumonia (VAP) is the most common healthcare-associated infection in adult critical care units. VAP is associated with increased length of stay in intensive care units (ICU), days in ventilator, and mortality by about $30 \%$. Because of the seriousness of the needs, VAP care bundle was introduced in 2007.
\end{abstract}

Objective -To assess the compliance to the ventilator care bundle in critical care units in the National Hospital Sri Lanka (NHSL).

Method - A descriptive cross-sectional study was conducted over a period of one month in ICUs in the NHSL. Evidence of compliance of the ventilator care bundle components were assessed using a standard data collection form. The assessed components were elevation of head of bed, adequate endotracheal tube cuff pressure, oral care with chlorhexidine, sedation vacation, peptic ulcer prophylaxis, and adherence to sub glottis suction. Ethical clearance was obtained from the Ethical review committee of NHSL.

Results - Adherence to all six components of the bundle was low as $28 \%$. Out of different ICUs at NHSL only three of them adhered to the total bundle care, namely medical, surgical and neuro trauma ICU. Head of bed elevation was adhered universally, and minimum adherence was shown to subglottic suction which was $39.08 \%$.

Conclusion - Total VAP care bundle compliance was low (28\%) in this study sample. Even though there is improvement of ventilator bundle care from 2011, overall practice was unsatisfactory and particular attention should be paid in terms of adherence to subglottic suction, oral care with chlorhexidine and sedation vacation.

Ventilator-associated pneumonia (VAP) is a nosocomial infection that develops in patients receiving mechanical ventilation for more than 48 hours and is the commonest intensive care units associated infection. ${ }^{1}$ Incidence is reported to be $10-60 \%$ and is highly influenced by the criteria used for diagnosis as there is no accepted universal criteria for diagnosis. ${ }^{2}$

\section{*Correspondence: Ruvini Jayanimali \\ Kosgollawatta Walimanna Gamage \\ E mail: malikosgollawatta@yahoo.com}

https://orcid.org/0000-0002-2639-5931

Received: 30/10/2018

Accepted:20/11/2018

DOI: http://doi.org/10.4038/slja.v27i1.8387

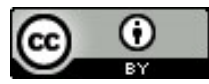

VAP is associated with increased length of stay in ICU, days in ventilator and increases mortality by about $30 \%{ }^{3,4}$. Initial VAP care bundle introduced in 2007 had four high impact (HII) interventions. Those are bed head elevation, daily sedation holds, prophylaxis for gastric ulcers, and oral hygiene.

High impact components were updated in 2010 to add oral hygiene with adequate strength anti-septic, subglottic suction, and cuff pressure monitoring. ${ }^{5}$.

Implementation of VAP care bundles has proven to reduce the rate of occurrence of VAP in ICU. Benefits are evident even when the compliance rates are poor as $30 \% .{ }^{6,7}$

As there are limited published data on this topic in Sri Lanka, this audit attempts to fill this gap. 


\section{Objective}

To assess the compliance to the ventilator care bundle in critical care units in NHSL.

\section{Audit standards and criteria}

\begin{tabular}{|c|c|c|c|c|}
\hline & $\begin{array}{l}\text { Evidence of } \\
\text { adherence to } \\
\text { VAP }\end{array}$ & $\begin{array}{l}\text { Standard } \\
\text { (\%compliance) }\end{array}$ & Exclusions & Definitions \\
\hline 1 & $\begin{array}{l}\text { Intubated } \\
\text { patients } \\
\text { should be } \\
\text { positioned in } \\
\text { semi- } \\
\text { recombinant } \\
\text { position }(30- \\
\left.45^{\circ}\right) \text { for as } \\
\text { much of the } \\
\text { time as } \\
\text { possible. }\end{array}$ & $100 \%$ & Spine injury & $\begin{array}{l}\text { All adult } \\
\text { intubated } \\
\text { patients in } \\
\text { ICU }\end{array}$ \\
\hline 2 & $\begin{array}{l}\text { Maintenance } \\
\text { of adequate } \\
\text { endotracheal } \\
\text { tube cuff } \\
\text { pressure. } \\
\text { Between } 20 \text { - } \\
25 \mathrm{cmH}_{2} \mathrm{O}\end{array}$ & $100 \%$ & None & $\begin{array}{l}\text { All adult } \\
\text { intubated } \\
\text { patients in } \\
\text { ICU }\end{array}$ \\
\hline 3 & $\begin{array}{l}\text { Oral hygiene } \\
\text { with } 0.5 \% \\
\text { Chlorhexidine } \\
\text { solution eight } \\
\text { hourly }\end{array}$ & $100 \%$ & $\begin{array}{l}\text { Oropharyngeal } \\
\text { trauma, allergy } \\
\text { to } \\
\text { Chlorhexidine }\end{array}$ & $\begin{array}{l}\text { All adult } \\
\text { intubated } \\
\text { patients in } \\
\text { ICU }\end{array}$ \\
\hline 4 & $\begin{array}{l}\text { Sedation must } \\
\text { be reviewed } \\
\text { and daily } \\
\text { sedation } \\
\text { vacation and } \\
\text { readiness to } \\
\text { wean and } \\
\text { extubation has } \\
\text { to be assessed. }\end{array}$ & $100 \%$ & $\begin{array}{l}\text { Difficult to } \\
\text { ventilate, } \\
\text { refractory } \\
\text { hypoxia, high } \\
\text { intra cranial } \\
\text { pressure }\end{array}$ & $\begin{array}{l}\text { All adult } \\
\text { intubated } \\
\text { patients in } \\
\text { ICU }\end{array}$ \\
\hline 5 & $\begin{array}{l}\text { Peptic ulcer } \\
\text { prophylaxis }\end{array}$ & $100 \%$ & None & $\begin{array}{l}\text { All adult } \\
\text { intubated } \\
\text { patients in } \\
\text { ICU }\end{array}$ \\
\hline 6 & $\begin{array}{l}\text { Using Endo } \\
\text { tracheal (ET) } \\
\text { tubes with } \\
\text { subglottic } \\
\text { suction }\end{array}$ & $100 \%$ & None & $\begin{array}{l}\text { All adult } \\
\text { intubated } \\
\text { patients in } \\
\text { ICU }\end{array}$ \\
\hline
\end{tabular}

\section{Methodology}

A descriptive cross sectional, baseline audit was conducted in all intensive care units in NHSL over a period of one month. Study population was adult patients who were intubated and ventilated during the study period. Pregnant and peripartum patients and patient who are under 16 years were excluded.

\section{Results}

Compliance on VAP care bundle was analyzed in 100 patients admitted to ICUs in NHSL. The total number of ventilatory days assessed were 417 (MICU- 109, NT- ICU 73, SICU-64, CICU-33, CTICU-18)
Table 1: Compliance to the VAP care bundle

\begin{tabular}{|l|l|l|}
\hline Compliance level* & $\begin{array}{l}\text { Number } \\
(\mathbf{4 1 7})\end{array}$ & $\mathbf{\%}$ \\
\hline $\begin{array}{l}\text { Compliance for all six components } \\
\text { of the bundle }\end{array}$ & 117 & 28 \\
\hline $\begin{array}{l}\text { Compliance for five components of } \\
\text { the bundle }\end{array}$ & 82 & 19.66 \\
\hline $\begin{array}{l}\text { Compliance for four components of } \\
\text { the bundle }\end{array}$ & 169 & 40.5 \\
\hline $\begin{array}{l}\text { Compliance for three components } \\
\text { of the bundle }\end{array}$ & 44 & 10.55 \\
\hline $\begin{array}{l}\text { Compliance for two components of } \\
\text { the bundle }\end{array}$ & 5 & 1.1 \\
\hline
\end{tabular}

*The compliance was calculated for total ventilator days

Total compliance to VAP care bundle was as low as $28 \%$. Highest compliance of $40.5 \%$ recorded for the compliance in four components.

Table 2: Compliance to total VAP care bundle (all 6 components) by different ICUs

\begin{tabular}{|l|l|}
\hline Different ICUs & $\begin{array}{l}\text { \% of } \\
\text { compliance }\end{array}$ \\
\hline Surgical ICU (SICU) & 48.43 \\
\hline Neuro Trauma ICU (NT-ICU) & 47.94 \\
\hline Medical ICU (MICU) & 46.78 \\
\hline Accident Service ICU (ASICU) & 0 \\
\hline Cardiology ICU & 0 \\
\hline Cardiothoracic ICU & 0 \\
\hline
\end{tabular}

Total bundle compliance was observed only in SICU, NT-ICU and MICU and it ranged from $46.78 \%$ to $48.43 \%$.

Figure 1: Adherence to total bundle care by different ICUs

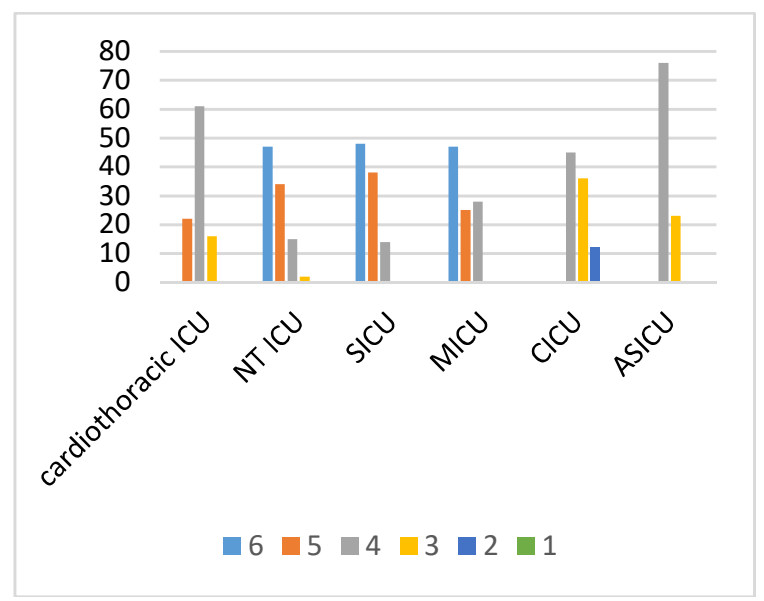


Almost all ICUs show higher percentage of adherence to four or more than four components of the bundle.

Table 3: Percentage adherence to individual components of the VAP care bundle

\begin{tabular}{|l|l|}
\hline Components & $\begin{array}{l}\text { Percentage } \\
\text { adherence } \\
(\mathbf{\%})\end{array}$ \\
\hline Head-of-bed elevation: 30 to 45 & 100 \\
\hline $\begin{array}{l}\text { Adequate endotracheal tube cuff pressure ( }>20-25 \\
\text { cmH2O) }\end{array}$ & 87.76 \\
\hline Oral care with chlorhexidine solution every $8 \mathrm{~h}$ & 67.38 \\
\hline $\begin{array}{l}\text { Daily "sedation vacation" and daily assessment of } \\
\text { readiness for extubation }\end{array}$ & 71.22 \\
\hline Peptic ulcer prophylaxis & 97.36 \\
\hline Subglottic suction & 39.08 \\
\hline
\end{tabular}

A $100 \%$ adherence was shown for head end elevation while the lowest $39.08 \%$ was recorded for subglottic suction.

Figure 2: Compliance for different components of VAP care bundle by ICU

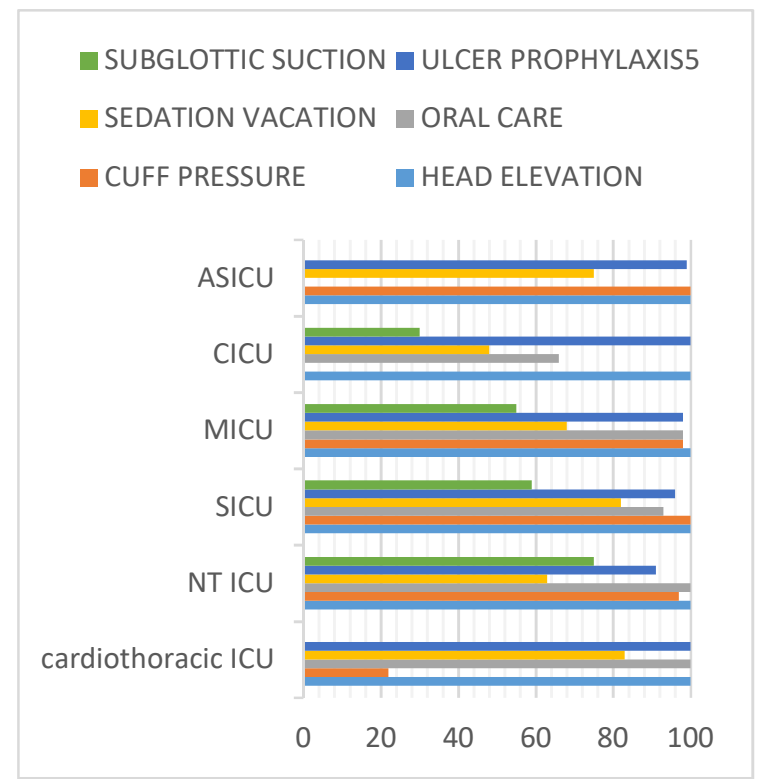

Oral care with chlorhexidine and adherence to subglottic suction were not practiced in the ASICU.

\section{Discussion}

A care bundle is defined as a group of evidencebased interventions related to a specific condition when applied together significantly improves patient outcome. Studies done worldwide have proven that adherence to VAP care bundle reduces the VAP rates. Compliance to all components of high impact interventions (HII) was very low (28\%) in this study sample. Highest percentage of $40.5 \%$ was shown with adherence to four components of the bundle. Significant reduction in VAP rates were shown by a large multi centered trial conducted in Scotland, by achieving 70\% adherence to total bundle care ${ }^{5}$. Another study done in Spain on HII showed that though, the compliance was $<30 \%$, there were significant reduction in VAP rate, length of stay and days of mechanical ventilation. $^{6,7}$

Only three ICUs in NHSL showed total adherence to VAP care bundle namely SICU, NT-ICU and MICU. Percentage compliance was $48.43 \%$, $47.94 \%$ and $46.78 \%$ respectively. Cardiothoracic ICU showed adherence to five components of the bundle of $22 \%$ and four components of $66 \%$. Compliance with four components of $44 \%$ recorded in cardiology ICU while ASICU showed $76.66 \%$.

$100 \%$ compliance was shown to head-of-bed elevation, which is the standard percentage compliance. When compared with the audit done in NHSL in 2011 this component was adhered only in $89 \%$ instances. $^{8}$ Thus, this is a clear improvement. Worldwide audits in this aspect have shown variation between $50 \%$ adherence to $100 \%$. Peptic ulcer prophylaxis was practiced in $97.36 \%$ of ventilator days, which is clearly closer to the recommendation. Non-adherence with this component was due to the negligence of the prescriber. In the audit in 2011 in the NHSL this component showed a percentage of $99 \%{ }^{8}$

Maintenance of ET cuff pressure is a proven factor to reduce the VAP rates. It was $87.76 \%$ in this audited sample. The previous audit documented a percentage of only $27 \% .{ }^{8}$ Over the years the practice of cuff pressure monitoring has improved dramatically. Main reason not to adhere to this component of the bundle was different VAP care guidelines practiced by different ICUs.

Sedation vacation and assessment for readiness for weaning and extubation is a common practice in critical care aiming to reduce the mortality and morbidity of these patients. It was adhered only in 
Gamage et al. Sri Lankan Journal of Anaesthesiology: 27(1):73-76(2019)

$71.22 \%$ (after excluding the exceptions like difficult to ventilate, refractory hypoxia, high intra cranial pressure) by the critical care units in NHSL. This is clearly substandard and almost no improvement from the audit in 2011 which showed $70 \%$.

Oral care with $0.5 \%$ chlorhexidine was introduced in 2010 to the HII bundle and compliance to that was $67.38 \%$. Audit performed in NHSL ICUs in 2011 chlorhexidine mouth wash was used only in cardiothoracic ICU. Thus, this is a significant improvement in nursing care in critically ill. ${ }^{8}$

Subglottic suction was not at all evident in the previous audit in the same population. But in this study sample it has improved from $0 \%$ to $39.08 \%$. Reason for not using sub glottis suction was nonavailability of the endotracheal tube with subglottic suction in every intensive care unit, theaters, trauma and emergency departments.

\section{Audit limitations}

Overall sample size obtained during the study period was limited. Improved validity would have been achieved by increasing the duration of the audit period.

Sample sizes from different ICUs are not equal, thus that would have affected the overall bundle compliance analysis.

\section{Audit recommendations}

The findings of the audit are to be discussed with relevant intensive care units to raise awareness among the doctors as well as critical care nurses on the ventilator associated pneumonia care bundle and encourage ongoing practice improvement. Necessary equipment like endo-tracheal tubes with subglottic suction should be made freely available. Critically ill ventilated patients would benefit from further frequent audit cycles to improve reliability of good practice. Incorporation of VAP care bundle to the daily nursing monitoring chart would improve the bundle care in the intensive care setup.

\section{Conclusion}

Total VAP care bundle compliance was very low $(28 \%)$ in this study sample. Even though there is improvement of ventilator bundle care from 2011, overall practice was unsatisfactory and particular attention should be paid in terms of adherence to subglottic suction, oral care with chlorhexidine and sedation vacation.

\section{References}

1. Vincent JL, Sakr Y, Sprung CL et al. Sepsis in European intensive care units: results of the SOAP study. Crit Care Med 2006;34: 344-53

https://doi.org/10.1097/01.CCM.0000194725.4892 $\underline{8.3 \mathrm{~A}}$

PMid:16424713

2. Young PJ, Ridley SA. Ventilator-associated pneumonia. Diagnosis, pathogenesis and prevention. Anaesthesia 1999; 54: 1183-97 https://doi.org/10.1046/j.1365-2044.1999.01035.x PMid:10594417

3. Vincent JL, Rello J, Marshall J et al. International study of the prevalence and outcomes of infection in intensive care units. J Am Med Assoc 2009; 302: 2323-9

https://doi.org/10.1001/jama.2009.1754

PMid:19952319

4. Kollef MH, Shorr A, Tabak YP et al. Epidemiology and outcomes of healthcare associated pneumonia. Chest 2005;128: 3854-62 Not cited in text. Remove or cite.

https://doi.org/10.1378/chest.128.6.3854

PMid:16354854

5. Morris AC, Hay AW, Swann DG et al. Reducing ventilator-associated pneumonia in intensive care: impact of implementing a care bundle. Crit Care Med 2011; 39: 2218-24

https://doi.org/10.1097/CCM.0b013e3182227d52 PMid:21666444

6. Rello J, Alfonso E, Lisboa $\mathrm{T}$ et al. A care bundle approach for prevention of ventilator-associated pneumonia. Clin Microbiol Infect 2013; 19: 363-9 https://doi.org/10.1111/j.1469-0691.2012.03808.x PMid:22439889

7. Zilberberg MD, Shorr AF, Kollef MH. Implementing quality improvements in the intensive care unit: ventilator bundle as an example. Crit Care Med 2009; 37: 305-9

https://doi.org/10.1097/CCM.0b013e3181926623 PMid:19050626

8. B K Udya Nirmalle Rodrigo. An audit on ventilator management in critical care units in National Hospital Sri Lanka. Sri Lankan Journal of Anaesthesiology 2012;20(2):78 - 83. https://doi.org/10.4038/slja.v20i2.4153 